\title{
GOD’S HIDDEN COMPASSION
}

\author{
Lena-Sofia Tiemeyer
}

\begin{abstract}
Summary
The present article looks at the divine restriction on intercession, attested in Amos 7:1-8:3; Jeremiah 7:16; 11:14; 14:11-12; Ezekiel 3:22-27; 24:27 and 33:21-22, and suggests that it is best understood as a way in which God safeguards his punitive plans from the forces of his own compassion. The divine declaration in Amos 7:8 and 8:2 is motivated by prudence: after having succumbed twice to Amos' intercession, God forestalls intercession as a means to protect himself and his plans of punishment. Likewise, God declares his intention to disregard any dissenting views that Jeremiah may have concerning God's planned punishment of Judah in order to ensure its execution. Lastly, God renders Ezekiel mute and confines him to his home so as to hinder him from interceding on behalf of the people.
\end{abstract}

\section{Introduction}

'Let me be, I have to cry. Do not try to comfort me when my people are being destroyed.' (Isaiah 22:4)

The biblical literary corpus bears witness to God's ambivalent feelings concerning the need to punish Israel, and his love and compassion for her. ${ }^{1}$ While many texts speak of a compassionate God who is always willing to transform his punitive plans into blessings, ${ }^{2}$ several others, particularly those describing the imminent fall of Samaria in $721 \mathrm{BC}$ or the fall of Jerusalem in 586 BC, present God differently. In these texts, God is perceived to be so angry with his people that he actively seeks

\footnotetext{
1 I am indebted to my colleague Dr P. J. Williams who weeded out more than one linguistic infelicity in this article.

2 E.g. Jer. 18:7-11.
} 
to ensure their punishment. In this article, I shall deal with but one textual feature, that of God restricting intercession.

Scholars have often understood this phenomenon as a way in which later authors attempted to remove any guilt from the prophets: since God had explicitly forbidden intercession, the prophets could not be held responsible for the people's lack of repentance and their subsequent punishment. The present article proposes a different way of looking at the situation: rather than focusing on the prophets, I suggest that the theme of restricting intercession touches our understanding of God. In portraying God as forbidding intercession, several biblical authors describe him as a God who can be overcome by his own compassion. In fact, as we shall discover, we receive a picture of a God who has to protect himself from the voices of intercession, because he cannot be sure that he will not be swayed by them.

A few scholars have hinted at such an interpretation earlier, ${ }^{3}$ yet they have not explored it in greater detail and they have limited the scope of the discussion to Amos 7:1-8:3; Jeremiah 7:16; 11:14; 14:1112. In view of this, a more detailed study is called for. First, there is a need to see if the interpretation of these particular verses in Amos and Jeremiah receives support from their context. Secondly, the question arises as to whether this particular theological perspective is part of a more widespread conviction shared by other biblical authors. In the present paper, I shall answer both questions in the affirmative: the idea of divine ambivalence towards intercession is well supported by the context in Amos and Jeremiah; and it is attested elsewhere, especially in Ezekiel 3:3:22-27; 24:27 and 33:21-22.

We shall begin with a brief look at the issue of intercession and at its connection to the prophetic office. Thereafter, we shall investigate the topic of the divine ban on prophetic intercession, beginning with a short overview of previous interpretations of the issue and a brief discussion of Exodus 32:10-14, followed by a more detailed discussion of the various prophetic texts.

3 See especially F. I. Andersen and D. N. Freedman, Amos (AB, 24a; New York: Doubleday, 1989): 616. 


\section{The Target: the Prophet}

We shall begin our discussion by looking at the prophets' intercessory roles. The prophets of the Hebrew Bible are often described as intermediaries, who stand between God and the people of Israel. As such, they have a dual role. On the one hand, the prophets are God's spokesmen who proclaim the need for repentance. On the other hand, they are the people's representatives who intercede on their behalf, asking God to look at them with compassion. In this way, both intercession and calling to repentance are integral to their duties; that is, they are 'part of their job description'. Removing either of these two parts would be to violate their prophetic calling.

\subsection{The Prophets and Intercession}

The claim that intercession was an important prophetic task has long been the common opinion. ${ }^{4}$ This claim, however, is challenged ostensibly by the fact that Jeremiah alone among the classical prophets seems to have regarded intercession as part of his prophetic office, while, at the same time, other people of various professions such as judges and priests are recorded as interceding: Abraham, Moses and Samuel are frequent intercessors while Nehemiah (Neh. 9) and Hezekiah (2 Chr. 30:18-20) intercede more sporadically. Job prays for his three friends in Job 42:7-10 and 'the servant' intercedes for the

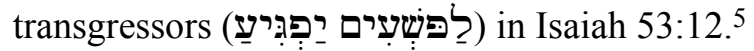

In response, it is correct that intercession was not limited to the prophetic office, but this in itself does not preclude it from being an integral part thereof. True, Moses and Samuel are described as frequent intercessors (Jer. 15:1; Deut. 34:10; Ps. 99:6), but, notably, they are also called prophets. ${ }^{6}$ It is therefore distinctly possible they are called

4 E.g. N. M. Sarna, Exodus (JPSTC; Philadelphia: Jewish Publication Society, 1991): 205. For a detailed discussion, see S. M. Paul, 'Prophets and Prophecy', EncJud 13: 1170-71, and A. B. Rhodes, 'Israel's Prophets as Intercessors, in Scripture in History and Theology', in Essays in Honor of J. Coert Rylaarsdam, ed. A. L. Merrill and T. W. Overholt (Pittsburgh: Pickwick, 1977): 107-28.

5 S. E. Balentine, 'The Prophet as Intercessor: A Reassessment', JBL 103 (1984): 161-73, esp. 162-64, and H. W. Hertzberg, 'Sind die Propheten Fürbitter?', in Tradition und Situation, ed. E. Würthwein and O. Kaiser (A Weiser Festschrift; Göttingen: Vandenhoeck \& Ruprecht, 1963): 63-74.

6 Gen. 20:7 (Abraham); Deut. 34:10; Num. 12:7 (Moses); 1 Sam. 3:20; 2 Chr. 35:15 (Samuel). In addition, the expression 'thus says YHWH' which signifies an oracle conveyed by a prophet, is used in the Torah only in connection with Moses (Exod. $4: 22 ; 5: 1 ; 32: 27)$. 
prophets because of their intercessory function. Abraham, for example, is called a prophet in the same context as he is described as someone

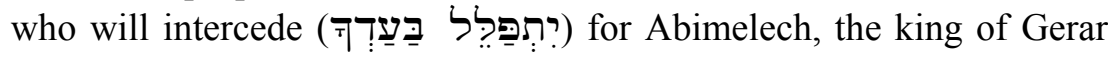
(Gen. 20:7). Thus, even if we argue that their prophetic office is a later addition to the traditions surrounding these characters, the fact that they are called prophets suggests that, at one point in time, intercessory prayer became closely linked with the idea of prophethood. Lastly, the

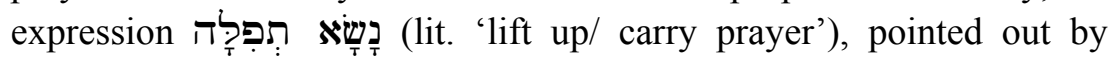
Balentine as an example of intercessory prayer not limited to prophetic activity, ${ }^{7}$ is in fact only attested with Isaiah and Jeremiah as the subject (Isa. 37:4; cf. $2 \mathrm{Kgs} \mathrm{19:4;} \mathrm{Jer.} \mathrm{7:16;} \mathrm{11:14).} \mathrm{In} \mathrm{view} \mathrm{of} \mathrm{this,} \mathrm{we} \mathrm{can}$ conclude that while the task of intercession was not restricted to the prophetic office, many, if not most, prophets were intercessors.

\subsection{God and Intercession}

The question then arises as to the purpose of prophecy in the first place: why does God inform his prophets about his future plans before executing them, and what is God's normal response to intercession?

More than one biblical passage testifies to the power attributed to intercession (e.g. Exod. 32:7-12; 1 Sam. 12:23; Ezek. 13:5; Ps. 106:23): if a person interceded, it would have an impact. On the basis of these passages, Miller states that intercession 'is expected by God and incorporated into the divine activity'. ${ }^{8}$ He further cites Wright who, in the context of Moses' intercession in Deuteronomy 9:25-29, argues that intercession is 'an integral part of the way God's sovereignty in history is exercised ... God not only allows human intercession, God invites it ... and builds it into the decision-making processes of the heavenly council in ways we can never fathom.' 9

Thus, it seems that God was expected to take the prophet's intercession into consideration when making decisions. Moreover, God was understood to be both just and compassionate, with a constant tension between these two characteristics. Indeed, it was assumed that God would let justice rule his decisions, but, at the same time, that he would delegate to the prophet the task of reminding him about his

7 Balentine, 'The Prophet as Intercessor': 166.

8 P. D. Miller, 'Prayer and Divine Action', in God in the Fray. A Tribute to Walter Brueggemann, ed. T. Linafeld and T. K. Beal (Minneapolis: Fortress, 1998): 211-32, esp. 219-20.

9 C. Wright, Deuteronomy (NIBC; Peabody, MA: Hendrickson, 1996): 140. 
compassion. In this way, God kept the door open to change: if the prophet, as the people's advocate, presented a convincing-enough case, then God would uphold his right to change his mind. ${ }^{10}$

\subsection{Exodus 32:10-14}

The prime example of the power of intercession is Exodus 32:10-14. In this passage, God is purportedly seeking to restrict intercession, as

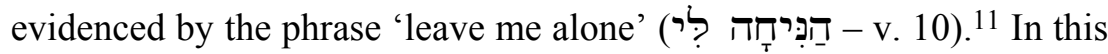
passage, God asks Moses to 'leave [him] alone' so that he can destroy the people of Israel and in their place make a new people out of Moses. In response (vv. 11-13), Moses intercedes, pleading with God to turn from his anger and to cancel his planned evil. Moses' intercession is

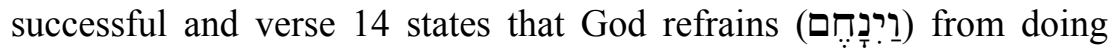
what he has threatened to do.

Scholars, both Jewish and Christian, have long suspected that the deeper message of the passage is not to ban intercession but to encourage it. In requesting to be left alone, God is in fact wishing the very opposite. ${ }^{12}$ In other words, by declaring his desire to destroy Israel, God gives Moses a reason to intercede, and by the words 'leave me alone' informs Moses that he had the power to hinder God from executing his threats. Thus, God is portrayed as someone who, in the midst of his conviction that Israel ought to be punished, wants his own punitive plans to be cancelled. Hence, by letting his prophets know about his plans beforehand, God opens the way to their cancellation.

Let us keep this portrayal of God in mind throughout the rest of the article, and let us ask ourselves what it means for the interpretation of the ban on intercession in Amos, Jeremiah, and Ezekiel. Did the ban

10 Cf. R. B. Coote, Amos among the Prophets. Composition and Theology (Philadelphia: Fortress, 1981): 94-95.

11 BDB: 629, translates the Hiphil of נוחד = 'let alone'; i.e. 'refrain from interfering

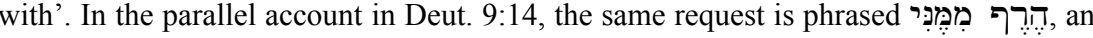
expression carrying roughly the same meaning (see BDB: 952).

12 See, among others, Tanhuma-Yelammedenu, Ki Tissa, 22 (Exod. 32:7); b.Ber. 32a, Ex. R.: 42,9; Rashi, Rabbinic Bible, Exod. 32:10; Ibn Ezra, Rabbinic Bible, Exod. 32:10; Theodoret, Quaestiones in Exodum, 67 (Theodoreti Cyrensis, Questiones in Octateuchum [Textos y Estudios "Cardenal Cisneros" 17; Madrid, 1979]: 148); Ephrem the Syrian, Commentary on Tatian's Diatessaron 14.27 (ed. and tr. C. McCarthy); Saint Ephrem's commentary on Tatian's Diatessaron. An English Translation of Chester Beatty Syriac MS 709 [JSSSup; Oxford, Oxford University, 1993]: 227); Jerome, Letter 128.4 (NPNF $2: 260)$; B. S. Childs, The Book of Exodus (OTL; Philadelphia: SCM, 1974): 567; Sarna, Exodus: 205. 
really intend to limit intercession in order to ensure the execution of God's punitive plans, or was it a veiled hint to do the very opposite?

\section{History of Interpretation}

In its present literary contexts, the ban on intercession in Amos, Jeremiah and Ezekiel is described as taking place before the imminent destructions of either Israel or Judah. Many scholars, however, argue that the texts containing the ban on intercession are later reflections on the fall of the northern and the southern kingdoms, inserted after the historical events.

Commonly, this post-catastrophe dating goes hand in hand with the assumption that these reflections were inserted into the earlier texts in order to vindicate the prophets. The claim that God either made his prophets mute and thus unable to intercede, or that God explicitly forbade them to intercede, exonerates the prophets from all responsibility for the catastrophe: the prophets would have interceded, had God just let them. ${ }^{13}$

This interpretation also emphasises God's responsibility. For example, Mays suggests that the ultimate purpose of Amos' visions was to show that God, rather than the prophet desired Israel's destruction: 'The judgment of Israel is not my will, for I have twice turned away the wrath of Yahweh by my intercession; it is Yahweh's final decree, and even intercession is now forbidden me.' 14

The alternative view, advocated here, is not necessarily to date these passages earlier - they may indeed be later reflections although there are in fact relatively few compelling reasons to date them late ${ }^{15}$ - but to

13 See especially R. R. Wilson, ‘An Interpretation of Ezekiel's Dumbness', VT 22 (1972): 91-104, esp. 104. Not all scholars agree with this. For a dissenting view, see T. Renz, The Rhetorical Function of the Book of Ezekiel (VTSup, 76; Leiden: Brill, 1999): 158-60, who regards the juxtaposition of Ezekiel's commission to be a watchman and Ezekiel's muteness to be editorial.

14 J. L. Mays, Amos (OTL; London: SCM, 1969): 126.

15 This present article is not the venue for an in-depth discussion of the different texthistorical theories related to Amos, Jeremiah and Ezekiel. For two conflicting datings of Amos's vision report, see, e.g. Coote, Amos among the Prophets: 8, 66, 89-95; and S. Paul, Amos (Hermeneia; Minneapolis: Fortress, 1991): 1, 6. In the case of Ezekiel, many scholars, e.g. Wilson, 'Ezekiel's Dumbness': 104, regard most of Ezek. 3 to be post-exilic. In contrast, M. Greenberg, Ezekiel 1-20 (AB, 22; Garden City: Doubleday, 1983): 15-17, 93, argues convincingly that the dates of the book are in line with the contents of its oracles. Jeremiah presents the most uncertain situation. W. Holladay, Jeremiah 1-25 (Hermeneia; Philadelphia: Fortress, 1986): 251, writes about the 
focus on the portrayal of God rather than on the prophets' responsibility. Hence, as we shall see, the ban on intercession creates the impression that God is aware of his compassionate predisposition and therefore seeks to safe-guard his own punitive decisions. Accordingly, since he cannot let compassion impede the execution of his punitive plans against Israel and Judah at these particular points in time, owing to the depth of their sins, God renders his prophets defunct; that is he removes the built-in advocators of leniency from his decision-making.

\section{Amos 7:1-8:3}

The earliest attestations of the idea of God limiting intercession in order to ensure the execution of his punitive plans are found in Amos 7:1-8:3 (esp. 7:8; 8:2). This passage consists of a report of four visions (7:1-9 and $8: 1-3)^{16}$ and of a prose narrative, situated between the account of the third vision and the account of the fourth vision (7:1017).

The account of the four visions forms a coherent whole. Although the prophet might have seen the visions over an extended period of time, they are presented in retrospective in their mutual relationship with each other - as two sequential pairs. ${ }^{17}$ All the visions predict the fall of the northern kingdom, but the outcome differs between the two pairs. From a form-critical perspective, their similarities in structure and content suggest that the four visions form a sequence, rather than four self-contained literary units. ${ }^{18}$ From an exegetical perspective, this sequence depicts a development in God's and Amos' communication. In this section, we shall discover that God's declaration that he will no longer spare Israel $(7: 8,8: 2)$ is best understood as the result of his

relevant passages that 'none of this is routine stereotyped prose', thus suggesting that these sayings belong in the oldest textual layers.

16 Amos' fifth vision (9:1-6) is irrelevant for the present discussion.

17 Even though Amos' visions are presented as one sequence of three visions (7:1-9) and one detached vision (8:1-3), a comparative study of the content and inner structure of each vision suggests that Amos 7:1-3 and 7:4-6 form one pair while 7:7-9 and 8:1-3 form another.

18 Cf. J. Jeremias, Der Prophet Amos (ATD, 24/2; Göttingen: Vandenhoeck \& Ruprecht, 1995): 96; Andersen and Freedman, Amos: 622. 
preceding decision to spare $(7: 3,6) .{ }^{19}$ Moreover, we shall discuss how Amos' proclamation of $\sin$ in the prose passage in 7:10-17 may fit into this development.

\subsection{The Four Visions}

Let us begin with the first of the two pairs of visions (7:1-6). After seeing the first vision of destruction, Amos responds with intercession. Although he is not invited to intercede, he does so spontaneously when witnessing the obvious threat that the vision portrays. He knows that the people of Israel are guilty and that their punishment is just, and therefore neither appeals to God's justice nor puts his hopes in Israel's hypothetical repentance. Instead, he pleads directly with God's compassion, seeking to evoke his pity for small Jacob, whose very survival is at stake. ${ }^{20}$ As a result, God reconsiders (נְחםם) and declares that the foretold destruction shall not take place. Likewise, after seeing the second vision, Amos asks God to cease the punishment, and again, God reconsiders and cancels the execution of his second plan.

In this way, strengthened by its twofold repetition, the reader receives the impression that Amos' intercession is powerful enough to change God's will. Not only that, God's change of mind is emotional: as Jeremias points out, the use of the niphal נחחם indicates that what is

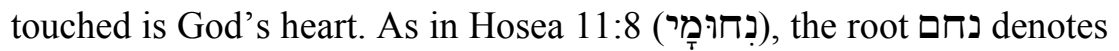
God's passion for his people, a passion that enables their survival. ${ }^{21}$ There is appeal to neither God's justice nor his election of Israel (cf. Ezek. 32:10-14), nor is there any expression of hope that Israel might repent. Instead, Amos turns to God, the Compassionate, who is concerned for the weak and the helpless.

Notably, however, there is a significant difference between the first plea 'to forgive' and the following 'to cease'. In a way, Amos' demands and God's concession decrease. The result of Amos's first intercession is not forgiveness but merely postponement of the punishment. Israel is never forgiven, it is only the particular type of

19 Cf. H. W. Wolff, Dodekapropheton 2: Joel und Amos (BKAT, 14/2; NeukirchenVluyn: Neukirchener, 1969): 350-51.

20 Jeremias, Amos: 98.

21 Jeremias, Amos: 99. Cf. H. van Dyke Parunak, 'A Semantic Survey of NHM', Biblica 56 (1975): 512-32, who argues convincingly that the niphal (and the hithpael) of this root carries the semantic range of 'compassion'. 
punishment envisioned that is cancelled. Hence, the second time, Amos only asks God to stop. Forgiveness is not an option. ${ }^{22}$

The second pair of visions brings about a change (7:7-9; 8:1-3). Again, Amos is shown a vision but several things have now changed. First, there is a difference in content: rather than seeing the actual destruction, Amos witnesses a symbolic act which expresses the fall of the nation. ${ }^{23}$ Secondly, there is a qualitative difference: while the first two visions contained a single exchange between the prophet and God, begun by God and ended by the prophet, the conversation in the second two visions is both initiated and concluded by God, thus emphasising God's control. The whole conversation is set up to permit the prophet neither initiative nor freedom to intervene, all in order to prevent another reversal. God is set on his course of action and will not be hindered. ${ }^{24}$ Thus, before Amos has had the opportunity to open his לא אוֹסיף - לאיס עוֹד עַבוֹר לו

In response, Amos is silent. We can understand his silence in two ways: either Amos is convinced of the uselessness of all intercession, ${ }^{25}$ or he understands God's declaration to be an explicit prohibition not to engage in it (cf. Jer. 7:16; 11:14 and 14:11 below). ${ }^{26}$ Given his intuittive intercession in the first two visions, combined with the inherent intercessory aspect of his prophetic office, the latter is more likely.

This perceived willingness of Amos to intercede is often understood to be the key to the interpretation of Amos' vision sequence as a whole. Regarding this is an apologetic text that seeks to exonerate the prophet from the responsibility of the later catastrophe, several scholars argue that the prophet would have interceded, had he but been given the opportunity. ${ }^{27}$ In this way, the prophet and his actions and thoughts take centre stage.

22 Cf. Wolff, Amos: 350, followed by Paul, Amos: 224, 230, 233.

23 E. Hammershaimb, The Book of Amos. A Commentary (Oxford: Blackwell, 1970): 111.

24 Andersen and Freedman, Amos: 614-15, 621-22.

25 E.g. Paul, Amos: 236.

26 J. A. Soggin, Amos (London: SCM, 1987; tr. from Italian, 1982): 114; J. D. Watts, Vision and Prophecy in Amos (Leiden: Brill, 1958): 49. Cf. Miller, 'Prayer and Divine Action': 218, who compares Amos' two last visions with Jer. 15:1, stating that in these three cases, the situation has gone too far for intercession to be effective.

27 E.g. Mays, Amos: 126; Andersen and Freedman, Amos: 622, 629. 
Whilst not ruling out this interpretation, it is possible to interpret the text differently, focusing on the way in which God is portrayed. In this regard, Jeremias' interpretation sheds new light on the passage. Jeremias sees this change from the first to the second vision pair as a decisive point at which Amos' prophetic function is fundamentally altered. Thus far, Amos was a mediator between God and Israel in that he possessed the knowledge of God's plans and was in a position to influence these plans to Israel's advantage. Now, his position has changed. On the one hand, his capacity is curtailed in that he no longer has the opportunity to intercede. On the other, his capacity is enhanced in that he is completely on God's side. In this way, Amos changes from being a messenger of God's compassion and patience to one of judgement. Moreover, this change legitimises the prophetic message of coming punishment. ${ }^{28}$

Jeremias' interpretation touches the very core of this passage: God's internal battle. To cite Jeremias, the concluding statement in the third

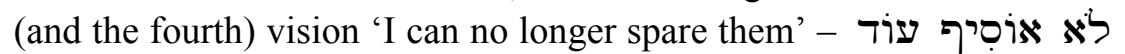
" עַבוֹר לו - "makes it clear that ultimately, the protective "wall of tin" (7:7) was God's own protection, protection not only against external enemies, but above all against himself, since he cannot bear, and indeed intends to punish, injustice and violence towards the weak among his people'. ${ }^{29}$ This internal divine battle is further emphasised by the fact that Israel is still referred to as 'my people Israel'. God may have decided to punish Israel but they remained 'his people', indicating that this was still a very painful decision to make. ${ }^{30}$ Furthermore, the contrast between the second and the third vision also highlights Amos' struggle with the limitation of his prophetic function. Israel is truly lost only when God prevents his prophets from fighting against God's plans of annihilation through the power of intercession. ${ }^{31}$

To conclude, the vision report in Amos 7:1-9 and 8:1-3 attests to a development in God's and Amos' communication. At first, Amos has the ability to stall God's planned punishment through intercession, but after using it twice successfully God takes away his ability. This

\footnotetext{
28 Jeremias, Amos: 96-97.

29 Jeremias, Amos: 103 (for the English translation, see The Book of Amos [OTL; London: WJK, 1998]: 133).

30 Paul, Amos: 236. Cf. W. Rudolph, Joel, Amos, Obadia, Jonah (KAT, 13/2; Gütersloh: G. Mohn, 1971): 236.

31 Jeremias, Amos: 97.
} 
development depicts a God who deprives his prophet of his intercessory ability because he fears his own compassion: after having succumbed twice to Amos' intercession, God is now trying to protect himself against his own love for Israel, and to ensure the execution of his decision to punish Israel. Therefore, as a way of forestalling any hypothetical intercession, God declares the finality of his destructive plans and his refusal to change his mind.

\subsection{Amos 7:10-17}

The juxtaposition of the narrative section in 7:10-17 to the vision report supports this interpretation. Within the vision report itself, Amos does not receive any commission for proclamation and there are no explicit references to Israel's sin, even though it is clearly presupposed (7:2). ${ }^{32}$ This absence is sharply contrasted by the content of the intersected narrative section where Amos is reported proclaiming repentance in Bethel, something that so annoys the high priest Amaziah as to cause him to ban Amos from Bethel.

The present arrangement of the material sketches a development in Amos' behaviour towards God and towards Israel. In the first two visions, Amos intercedes with God but does not proclaim repentance to Israel. In the third vision, Amos is silent. In the prose narrative, Amos proclaims to Israel but does not intercede, and finally, in the fourth vision, Amos is again silent. What this narrative pattern implies is the interplay of Amos's two main prophetic functions; intercession and proclamation. In the first two visions, Amos intercedes in order to save the people of Israel. After God's stated intention in the third vision to exercise no further forbearance on the people's behalf, the prose narrative portrays Amos as fulfilling his second prophetic function; i.e. that of proclamation. In other words, having lost the opportunity to intercede, the only remaining possibility to save Israel from destruction is to call them to repentance. Unfortunately, they do not listen, and Amos is once more forbidden to speak; this time not by God but by the high priest of Bethel. Finally, in Amos' fourth vision, God declares anew that he will not give Israel another opportunity to be saved. By now, Amos has exhausted his responses and what remains is silence (דָ 'hush' - 8:3).

\footnotetext{
32 Jeremias, Amos: 95.
} 


\section{Jeremiah}

The idea that God seeks to safeguard his decision to punish can be found also in the book of Jeremiah. While the divine ban on prophetic intercession in Amos was inferred primarily from God's declaration not to have mercy upon Israel, the situation described in Jeremiah is more direct: instead of having an open discussion with Jeremiah about his punitive plans for Judah, God declares that he plans to disregard any dissenting views that Jeremiah may have. Jeremiah is forbidden to intercede, and if he were nevertheless to do so, God emphasises his intention not to listen by declaring that he 'will not hear' Jeremiah. This lack of reciprocal conversation is God's deliberate choice. ${ }^{33}$

Jeremiah 7:16, 11:14 and 14:11 express God's ban on intercession, with slight variations: 'and you, do not pray on behalf of this people

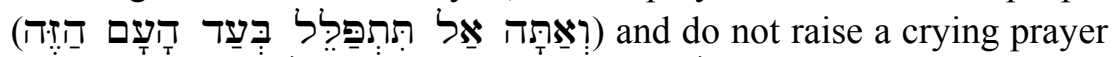

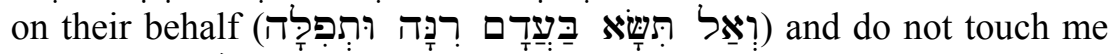

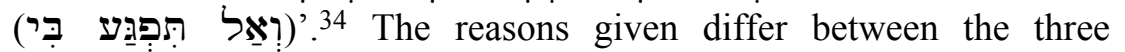
attestations, yet the concept of God's refusal to listen remains the same

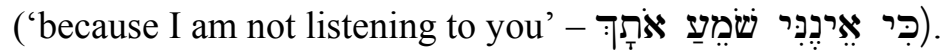

How can we best understand these statements? One way is to see them as simple predictions of failure: since God is not planning to listen, there is no point in interceding, and accordingly, Jeremiah should save himself the effort. This interpretation, however, is counterintuitive. As Miller aptly comments, 'there is no reason why the prophet should withhold intercession unless it is going to have some effect on the Lord's response to the people.' Were this simply a matter of ignoring the intercession, there would be no point in restraining the prophet. 35

Alternatively, I suggest that, as in the case of Amos 7:6-9 and 8:1-3, God is banning intercession because he fears its persuasive power. Three key aspects of the ban support this interpretation.

First, there is an urgent aspect to God's ban on intercession. Rather than being phrased as a factual prohibitive ('you shall not pray'), it is

33 Cf. Holladay, Jeremiah: 253.

34 The beginning of Jer. 11:14 is identical to that of Jer. 7:16 apart from the last clause 'do not reach out to me' which is not attested. In Jer. 14:11, the command reads, 'Do not pray for the welfare of this people.'

35 Miller, 'Prayer and Divine Action': 218. 
an imperative command 'do not pray' (אֵ). Furthermore, its threefold repetition testifies to the urgency of the matter.

Secondly, the imperatives introduce a temporal aspect: Jeremiah is forbidden to pray at this particular point but will be free to pray later. ${ }^{36}$ This is significant when taking into account when that later time is after the fall of Jerusalem (e.g. Jer. 37:1-10; 42:1-17). Hence, the temporal aspect underscores that the very purpose of the ban is to enable God to execute his punitive plans undisturbed. It also provides a parallel to Ezekiel's muteness (below), which again lasts only until Jerusalem's destruction. ${ }^{37}$ Hence, both prophets' ability to oppose God's decision to punish is restricted until a time when all interventions would be too late and, as such, inconsequential.

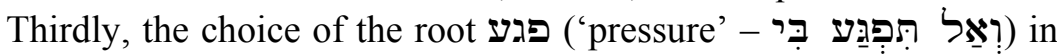
Jeremiah 7:16 brings out the emotional aspect of the ban. The point here seems to be that Jeremiah is pressing God 'more than he should'. Even though God does not want to relent, Jeremiah is pressing him in the hope that he will. ${ }^{38}$

Isaiah 59:16 expresses a similar, yet reverse idea. In this verse, the

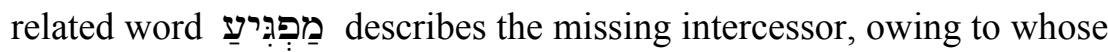
absence God himself steps in. Thus, the Isaianic author assumed that God needed someone to compel him into helping his people. As such, this verse testifies anew to the view that prophetic intercession was considered a vital part of God's decision-making (cf. above). When intercession is absent, God's decision-making becomes unbalanced.

In addition, God's command against intercession violates Jeremiah's prophetic calling. ${ }^{39}$ The unnaturalness of this behaviour is highlighted by God's and Jeremiah's subsequent statements and actions. On God's part, the fact that God feels the need to justify his prohibition conveys a nuance of unease (7:18-19). On Jeremiah's part, the prophet refuses to obey God's command. He is so absorbed into his prophetic task of interceding and proclaiming repentance that he cannot be silent (e.g. Jer. 4:19). At a time of drought, a mere foreshadow of God's planned final destruction of Jerusalem, Jeremiah breaks God's ban and pleads

36 See J. Bright, 'The Apodictic Prohibition: Some Observations', JBL 92 (1973): 185-204, esp. 186, for the temporal aspects.

37 Cf. Holladay, Jeremiah: 253-54.

38 See, e.g. J. Lundbom, Jeremiah 1-20 (AB, 21A; New York: Doubleday, 1999): 474; and W. McKane, Jeremiah, 1 (ICC; Edinburgh: T\&T Clark, 1986): 169.

39 Cf. Holladay, Jeremiah: 253. 
with God on behalf of Judah. Not only that, he continues to break it by his persistence in interceding in Jeremiah 18:20, using some of the very

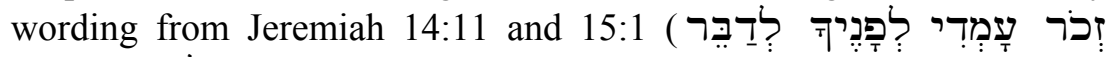

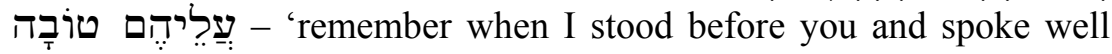
about them' - see further below).

To sum up, God's ban on intercession is portrayed as an urgent, temporal and emotionally burdened decision. As such, rather than being a prediction of failure, the ban admits to God's involvement in and his concern for the situation. Moreover, God's ban on intercession violates the core of Jeremiah's prophetic calling, thus indicating that God is attempting to alter the regular course of events. Normally, God's decisions to punish would be open for discussion. The fact that they are not is suggestive of a situation where God is trying to safeguard his planned punishment by rendering himself immune to any voice appealing to his compassion.

\subsection{Jeremiah 7:16}

A closer look at all three relevant Jeremianic passages confirms this impression. Beginning with Jeremiah 7:16, the ban on intercession follows immediately after the account of his temple sermon in Jeremiah 7:1-15. Given the textual proximity, the temple sermon serves as the background of the ban on intercession. There are two versions of this sermon. Here, the longer form is attested whereas a shorter version is found in Jeremiah 26:4-6. I suggest that a key to understanding the prohibition against intercession lies in a reading of the two versions of the temple sermon side by side: given that the two texts record the same event, one text may serve as an inner-biblical interpretation of the other. ${ }^{40}$

The longer version in chapter 7 describes a situation without much hope of change. Even though 7:7 states that repentance would result in eternal residence in Judah, the following verses declare that such hope is futile: as God banished Ephraim from his presence due to its wickedness (v. 15), so will he now banish the people of Judah because of their present evil deeds and their refusal to listen to him (v. 13).

In contrast, the shorter version of the sermon in 26:4-6 is rendered more hopeful by its immediate context. In the preceding context of

40 Scholars disagree about which of the two texts is the original version. For an overview, see Holladay, Jeremiah: 240. 
verses 1-3, God expresses the hope that Jeremiah's preaching might bring the people to repentance. If so, then God declares himself willing to reconsider (niphal of נחם) the evil which he has planned for them and to cancel his punitive plans (26:3). The same hope is also expressed by Jeremiah after the sermon (26:13) as well as by the following account of Micah from Moresheth. This prophet proclaimed God's predicted punishment, thus succeeding in causing Hezekiah and the people of Judah to repent and hence to annul the prediction. As a whole, this passage bears witness to the tremendous prophetic power of bringing about a change in people's hearts, and subsequently a change in God's plans (26:19), even though the focus is on repentance rather than intercession.

The two versions of the same event create a poignant picture of the power of intercession and of God's attitude towards a change of heart. Chapter 26 highlights God's willingness to change and the prophetic power to bring it about. In contrast, chapter 7, with its ban on intercession and the absence of a powerful interceding prophet, portrays a God unwilling to change. Furthermore, placing both narratives side by side provides us with insight into God's reasoning for silencing his prophets. As we learn from Jeremiah 26, the prophets had tremendous influence over God's decision. Thus, if God needed to remain firm on a particular decision, what better way to safeguard it than by silencing his prophets?

\subsection{Jeremiah 11:14}

In the case of Jeremiah 11:14, our proposed interpretation is again supported by the immediate context of the ban. This time, the ban against intercession is juxtaposed to a divine lament (11:15-16). Despite the textual difficulties of the lament, it is nevertheless clear that it portrays a compassionate God who exclaims in passionate, albeit obscure, wordings of how 'his beloved' ought not to be in his temple due to her shameful behaviour, since no burnt offering could save her now. Similarly, God likens his people with a 'luxurious, beautiful olive tree'. By using the two epithets 'beloved' and 'luxurious beautiful olive tree', the text emphasises God's love for his people and his sorrow at her destruction. Hence, we find that God's ban against intercession in 11:14 appears together with God's declaration of his ambiguous feelings for Judah: on the one hand, God loves her and has compassion for her, but, on the other, he needs to punish her. This display of God's 
conflicting feelings makes it again unlikely that his ban against intercession is a mere statement of its futility. On the contrary, it is God's (only) way of making sure that nothing can come between him and his destructive plan.

\subsection{Jeremiah 14:11-12 and 15:1}

Lastly, the ban against intercession is repeated a third and final time in Jeremiah 14:11-12, a part of the longer section of Jeremiah 14:1-15:3, 4, 9. 41 This section, however, differs significantly from the other two with regard to the tension between compassion and punishment. Both Jeremiah 7:11 and 11:14 testify to a tension within God, between God's expressed prohibitions against intercession on the one hand, and his feelings or sayings of love and compassion attested in the same context on the other.

In contrast, while there is a marked dissonance in Jeremiah 14:11-12 as well, it is expressed by the contrast between God's ban on the one hand and the sentiments expressed in the surrounding laments (14:7-9, 19-22) on the other. In the latter, a group of people, speaking in the first person plural, pleads twice with God to abandon his punitive plans and instead to side with his people. Contrariwise, God remains steadfast in his prohibition. In response to the first lament, God forbids Jeremiah to intercede (14:11-12). In this way, the juxtaposition of the lament and the ban on intercession suggests, at least from the point of view of a later redactor, that Jeremiah participated in the lament. Likewise, following the second lament, God declares that intercession would be futile (15:1). Not even Moses and Samuel, the great intercessors of old, would be able to convince God to take back his people. In fact, God is tired of showing compassion (15:6).

Thus, this last text contains none of the hope found in the other two; instead it sounds a note of finality: regardless of any act of intercession or repentance, the fate of the city is sealed (14:12). There is no point in interceding for Judah because she has in fact already fallen.

41 There is little agreement concerning the division of the text. On this matter, see R. P. Carroll, The Book of Jeremiah (OTL; London: SCM, 1986): 307. Furthermore, the present literary unit is likely to be secondary, composed of material of different dating (J. Bright, Jeremiah [AB, 21; New York: Doubleday, 1965]: 103). 


\section{Ezekiel}

Leaving the book of Jeremiah on this rather negative note and turning to the book of Ezekiel, we find the idea of God as actively hindering intercession reaching its peak. While the ban in Amos and Jeremiah is expressed verbally, the ban in Ezekiel is physical: Ezekiel is confined to his home and is rendered mute. Ezekiel 3:22-27, immediately following Ezekiel's call to become a watchman (3:16-21), tells how Ezekiel is informed by God to shut himself in his house where he will be restrained. ${ }^{42}$ The reason for these actions, while not explicitly stated, can be inferred from the general context: Ezekiel's isolation serves to prevent him from associating with the rest of the community on his own volition (3:25). People can visit him (e.g. 14:1; 20:1) but he cannot visit them. Moreover, God makes Ezekiel's tongue cleave to the roof of his mouth in order to render him mute (v. 26a).

\subsection{The Place of Ezekiel's Muteness within the Book of Ezekiel}

In order to estimate correctly the significance of Ezekiel's muteness, we must begin by discussing the phenomenon against the background of the book of Ezekiel as a whole. This book can be divided roughly into three main parts: chapters 4-24 are oracles of sin and judgement against Israel; chapters 25-32 contain oracles against the nations; and chapters $33-37$ and $40-48$ contain prophecies of restoration. ${ }^{43}$ Thus, the references to Ezekiel's muteness and to his subsequent renewed ability to speak occur at significant textual turning points. He is made mute immediately following his call to be a watchman and just prior to the section containing oracles of doom $(3: 22-27)$. The end of his muteness is predicted at the very end of the same section (24:27) and manifested in the very beginning of the third section (33:22). Since the oracles between the two latter references do not concern Israel, these

42 The Hebrew text has plural active verbs. Some scholars, e.g. N. J. Tromp ('The Paradox of Ezekiel's Prophetic Mission', in Ezekiel and his Book. Textual and Literary Criticism and their Interrelation, ed. J. Lust [Bibliotheca Ephemeridum Theologicarum Lovaniensium; Leuven: Leuven University, 1986]: 201-13, esp. 209), understand this to indicate that they people around Ezekiel were the subject, translating 'they confined him'. However, Hebrew can use active plural in order to create a passive sense. Therefore, other scholars, e.g. Wilson, 'Ezekiel's Dumbness': 98, see this as an impersonal statement that Ezekiel 'was restrained', with no explicit subject. In the latter case, God may be the intended agent (cf. v. 26).

43 Cf. M. Fishbane, 'Sin and Judgment in the Prophecies of Ezekiel', in Interpreting the Prophets. Biblical Texts in Literary Focus, ed. J. L. Mays and P. J. Achtemeier (Philadelphia, Fortress, 1987): 170. 
two references become directly linked. Accordingly, with one exception, the prophet refrains from speaking of Israel's fate between these two attestations. The exception is Ezekiel's second call to be a watchman (Ezek. 33:7-9) which refers back to the near identical call immediately preceding the account of Ezekiel's muteness in chapter three. In this way, the person responsible for the final layout of the book of Ezekiel paints the following generalised picture: Ezekiel is called to be a watchman; he is made mute; he utters oracles of sin and judgement; he is called anew to be a watchman; and soon afterwards his muteness disappears. Thus, Ezekiel's muteness emerges as a key motif for the interpretation of the book as a whole.

\subsection{The מיש מוכידת}

The main consequence of Ezekiel's muteness is that it renders him unable to function as an (3:26). Unfortunately, the exact

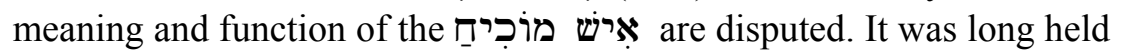
to signify a person whose main task was to 'reprove' another party. ${ }^{44}$ Yet this interpretation disagrees with the content of the rest of the book of Ezekiel. Not only is Ezekiel recorded as having reproved Judah several times in the material following 3:26 (e.g. 6:1-14; 7:1-27), ${ }^{45}$ it also contradicts Ezekiel's preceding call to become a watchman (3:1621 ; cf. 33:7-9). In view of these difficulties, Wilson proposes the translation 'mediator' or as 'arbitrator', a translation supported mainly by Hosea 4:4. By using the particular term מִישׁ מוֹכִיח, the author of Ezekiel 3:26 thus alludes to the legal context of the divine dispute. The function of the אִיש מוֹכִיח would then be to promote dialogue between two parties rather than to reprove one of them. Accordingly, after having been told not to be an מִיש מוֹכִיחָ, Ezekiel could still be able to reprove the people but would be hindered from mediating in the dispute between the people and God. In other words, while he could neither initiate communication between the two parties nor intercede

44 E.g. W. Eichrodt, Der Prophet Hesekiel (ATD, 22; Göttingen: Vandenhoeck \& Ruprecht, 1966): 21 ('Wahner'); J. W. Wevers, Ezekiel (NCB; London: Marshall, Morgan \& Scott, 1969): 58 ('reprover').

45 Note, however, that most of the oracles in Ezekiel were spoken to Ezekiel. In fact, there is very little trace of what he actually said to the exiles (cf. C. Sherlock, 'Ezekiel's Dumbness', ExpTim 94 [1983]: 296-98). 
with God on behalf of the people, he would still be able to fulfil his task as a watchman by warning the people of the coming doom. ${ }^{46}$

Yet despite its suitability in the present context, this proposal has not won universal acceptance, and the earlier translation 'reprover' has often been retained. ${ }^{47}$ More recently, however, several scholars have

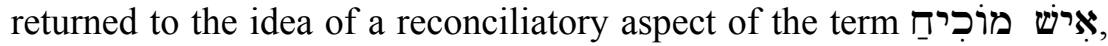
and they have demonstrated that the root יכח carries shades of 'arbitrating' or 'taking sides', especially when followed by the preposition ('between'; Gen. 31:37; Job 9:33) but also in other cases (Gen. 24:14, 44; 31:42; Job 16:21). ${ }^{48}$

Summing up, there is textual evidence suggesting that the root carries the meaning 'to intermediate'; but in view of more recent research, a more nuanced translation is preferable. Therefore, I suggest translating the term אִיש מוֹכיזיח as 'a man who intervenes'. Thus, by being rendered mute, Ezekiel is barred from intervening in the present situation. God can speak through him but he cannot take any initiative on his own, neither to intercede nor to proclaim repentance. This works on both a human and a divine level. By not being able to call to repentance, Ezekiel cannot influence the people around him beyond what God explicitly tells him to do. At the same time, by not being able to mediate, the prophet cannot influence God's plans.

\subsection{The Prophet's Loss of Independence}

By confining Ezekiel to his house and by making him mute, Ezekiel's prophetic calling is diminished and, as a result, the people's ability to return is curtailed. By making him mute, God destroys Ezekiel's ability to plead the people's cause and thus to alleviate their punishment. Moreover, God's actions almost but not completely annul Ezekiel's very recent calling to be a watchman. Immobile in his house and with his tongue stuck to his palate, he is largely unable to call out to the

46 Wilson, 'Ezekiel's Dumbness': 98-101; followed by, among others, M. S. Odell, 'The Inversion of Shame and Forgiveness in Ezekiel 16,59-63', JSOT 56 (1992): 10112, esp. 106; and G. A. te Stroete, 'Ezekiel 24,15-27: The Meaning of a Symbolic Act', Bijdragen 38 (1977): 163-75, esp. 173-74.

47 See, e.g. Greenberg, Ezekiel, 102, and Tromp, 'Paradox', 210. Cf. also BDB, 407a, Hiphil 5b. The similar expression, מוכיח בשער occurs in Amos 5:10 and Isa. 29:2021.

48 See especially P. Bovati, Re-establishing Justice: Legal Terms, Concepts and Procedures in the Hebrew Bible (JSOTS, 105; Sheffield: JSOT, 1994; tr. from Italian, 1986): 44-48; and Renz, Rhetorical Function, 157-62. 
people and to warn them of the coming danger. He can proclaim God's will to the people only when God prompts him (3:27), but scant success in the endeavour is predicted. In this way, as in the case of Jeremiah described earlier, Ezekiel's lost ability to intervene touches the very core of his prophetic calling. Ezekiel loses his independence, albeit freely surrendered. ${ }^{49} \mathrm{He}$ cannot go anywhere and he can only speak when God wants him to speak and then only what God wants him to say. As a result, Ezekiel has ceased to be an independent agent and has become someone with God's point of view.

A milder form of this idea is already present in Ezekiel's call vision (Ezek. 3:1-4) where the eating of the scroll indicates that God has supplied Ezekiel with fixed oracles that cannot be changed. Again, the result is the loss of his prophetic ability to mediate: by incorporating God's words into his body, he can no longer stand between God and Israel as a buffer facing in both directions. Instead of speaking his own words or those of the people (cf. Ezek. 3:4) he has become utterly absorbed by God, speaking his words alone..$^{50}$

It has been argued that Ezekiel's prophetic authority gained from of this loss of independence: due to his muteness and his incorporation of God's words, the result was absolute certainty of the divine authority and origin of the prophet's words. Hence the people would know that God, and God alone, was speaking, and accordingly, there would be no danger of Ezekiel being perceived as a false prophet. ${ }^{51}$ This interpretation, however, is unsatisfactory in that it has as its basis the presupposition that Ezekiel's contemporaries were familiar with the divine origin of his muteness. Furthermore, it assumes that Ezekiel's message, from its very beginning, was presented in its entirety, in a form similar to the book of Ezekiel that we have today, rather than constituting separate oracles that were delivered orally one by one.

49 Some scholars commend Ezekiel for his willingness, e.g. J. Calvin, 'Lecture 10', Ezekiel, vol. 1 (COTC; Grand Rapids: W, B. Eerdmans 1994; tr. from Latin): 104-5. Others are more critical, such as R. R. Wilson, 'Prophecy in Crisis: The Call of Ezekiel', in Interpreting the Prophets, ed. J. L. Mays and P. J. Achtemeier: 157-69, esp. 165, who labels him 'an automaton', and Tromp, 'Paradox', 209, who calls him 'a paralysed messenger, a dumb mouthpiece [whose] mission is fundamentally subverted by the very master who sends him'.

50 M. Greenberg, 'On Ezekiel's Dumbness', JBL 77 (1958): 101-5; and E. F. Davis, 'Swallowing Hard: Reflections on Ezekiel's Dumbness', in Signs and Wonders, ed. J. C. Exum (Semeia Studies; USA: Society for Biblical Literature, 1989): 228-30.

51 Tromp, 'Paradox', 210, Wilson, 'Prophecy in Crisis': 165-66; Renz, Rhetorical Function: 159-60. 
Thus, unless we presuppose that Ezekiel's audience read his book from beginning to end, there are no reasons to assume that the account in Ezekiel 3:22-27 was public knowledge. On the contrary, God requests Ezekiel to meet him in the valley (vv. 22-23), presumably a place where they could converse undisturbed. Hence, while Ezekiel himself could be adequately sure of speaking only God's words, his audience would have no such surety. From their perspective, Ezekiel would have been one among the prophets, characterised merely by his conciseness.

\subsection{The Divine Gain of Unimpeded Execution of Punishment}

If Ezekiel's muteness seriously impeded his ability to function as a prophet, did it have an equally significant impact on God? On this issue, those exegetes who understand אִיטש מוֹכִיח to mean 'reprover' commonly argue that Ezekiel's muteness was a symbol of God's withdrawal from his people. Instead of calling them to repentance, which could hypothetically have caused them to reform their lives, God's silence leaves them without guidance, left to their own council.52 By understanding the אִיט מוֹכִיח as a mediator, however, a different interpretation becomes preferable. The key is found in the specific circumstance of the lifting of Ezekiel's muteness: God opens Ezekiel's mouth when the news of the fall of Jerusalem $(24: 27 ; 33: 22)$ reaches him. Immediately prior to that, Ezekiel had received a second call to be a watchman (33:1-20). These two events - the fall of Jerusalem and the second call to be a watchman - together suggest their interpretation. With the destruction imminent and unavoidable, Ezekiel renewed calling is void of practical meaning: the coming destruction is for all to see and there is no escape. Likewise, Ezekiel's renewed ability to speak is useless: the destruction is a fact and no intercession can change that. Thus, the text of Ezekiel as a whole suggests that the emphasis in Ezekiel 33 is not on what words Ezekiel will speak now ${ }^{53}$ but on what he would have spoken prior to this date, had he had his oral facilities in place. By thwarting Ezekiel's prophetic abilities, God dislodged his human partner in the decision-making process. As a result, God's heart,

52 Tromp, 'Paradox': 211-12. Interestingly, he also states that 'By means of striking the prophet with dumbness YHWH provides himself with the competence required for the realization of his program' (209).

53 For suggestions, see e.g. Odell, 'Inversion of Shame': 106, who states that the fall of Jerusalem gave Ezekiel the renewed ability to address the complaint of the exiles; and J. M. Kennedy, 'Hebrew Pithôn Peh in the Book of Ezekiel', VT 41 (1991): 23335 . 
always prone to compassion, was safeguarded from change, with the result that he was able to carry out his destructive plans unhindered.

The notion of God who, through prone to compassion, has taken sides against himself to be able to execute punishment, fits well with the rest of the message of Ezekiel. In particular, Ezekiel 18:21-32 and 22:30 lend their support to this interpretation.

Beginning with the former, Ezekiel 18:21-32 testifies to the belief that God takes no pleasure in the death of the wicked, and that he would rather see a person repent and be saved than see him punished (v. 23). Not only that, the section as a whole speaks about God's changeability. In response to the people's accusation that God's way is not always the same (vv. 25, 29), God answers that it is their way which has changed (cf. Ezek. 33:17). It is thus clear that God accommodates his behaviour to that of the people. In this case, the key issue is repentance. In others, it may be intercession. The God of Ezekiel is not static but adopts his actions to fit those of his people, for better or for worse (cf. Jer. 18:7-10).

In the case of the latter, Ezekiel 22:30 speaks about 'someone who stands in the gap' (cf. Isa. 59:16; 63:5). This metaphor is only attested in Psalms 106:23 where it refers to Moses' intercession (cf. Exod. 32:10-14) and here in Ezekiel 13:5 and 22:30. In all three cases, the idea behind the metaphor is of a prophet who stands between God and the people as a buffer in order to avert God's anger and thus to save the people from annihilation. Ezekiel 13:5 is a message against some of the prophets of Judah who, owing to the falsehood of their prophecies and visions, have failed to 'stand in the gap' and to 'build up the wall', and thus have caused the people's perdition. In other words, they failed to announce God's punishment and consequently they failed to bring about repentance..$^{54}$

The oracle in Ezekiel 22:23-31 addresses a similar situation, speaking of the corruption among the leaders of Judah. Against the background of the priests' and the prophets' sacrilegious and violent deeds, Ezekiel declares that 'I demanded from among them a person who would build a wall and who would stand in the gap before me for the sake of/in defence of the land in order that I may not destroy it, but I did not find him.'

54 Y. Muffs, Love \& Joy - Law, Language and Religion in Ancient Israel (New York: Jewish Theological Seminary of America, 1992): 31. 
In view of this, the Ezekielian material contains a strong tradition of God as one who takes intercession into account in his decision-making, and who takes no pleasure in the punitive side of his justice. ${ }^{55}$

\section{Conclusion}

A significant part of the message of the Amos, Jeremiah and Ezekiel is the inevitable destruction of Israel and Judah. The question is, who needed to be convinced of the coming destruction: the people or God? A close reading of several texts in Amos, Jeremiah and Ezekiel suggests the latter, as they depict a God who endeavours to safeguard his punitive plans against intercession. Thus, we find that when the biblical authors describe God as truly wanting to punish his people, God is often depicted as one who limits reciprocal communication between himself and his prophets. By banning intercession, God seeks to ensure that nothing shall come between himself and the execution of his planned punishment.

55 B. Lindars, 'Ezekiel and Individual Responsibility', VT 15 (1965): 452-67, esp. 466-67. 